\title{
Harbour porpoises (Phocoena phocoena) stranded along the southern North Sea: An assessment through metallic contamination th
}

\author{
Céline Mahfouz ${ }^{\mathrm{a}, \mathrm{b}, \mathrm{c}, \mathrm{d}, *}$, Françoise Henry ${ }^{\mathrm{a}, \mathrm{b}, \mathrm{c}}$, Lucie $\operatorname{Courcot}^{\mathrm{a}, \mathrm{b}, \mathrm{c}}$, Sylvain Pezeril ${ }^{\mathrm{e}}$, \\ Thibaut Bouveroux ${ }^{\mathrm{e}}$, Willy Dabin ${ }^{\mathrm{f}}$, Thierry Jauniaux ${ }^{\mathrm{g}}$, Gaby Khalaf ${ }^{\mathrm{d}}$, Rachid Amara ${ }^{\mathrm{a}, \mathrm{b}, \mathrm{c}}$ \\ ${ }^{a}$ University of Lille Nord de France, France \\ ${ }^{\mathrm{b}}$ Université du Littoral, Laboratoire d'Océanologie et de Géosciences, 32 Avenue Foch, BP 80, F-62930 Wimereux, France \\ c CNRS, UMR 8187, F-62930 Wimereux, France \\ ${ }^{d}$ CNRS, National Centre for Marine Sciences, P.O. Box 534, Batroun, Lebanon \\ e Observatoire pour la Conservation et l'Etude des Animaux et Milieux Marins- OCEAMM, F-59123 Zuydcoote, France \\ ${ }^{\mathrm{f}}$ Centre de Recherche sur les Mammiferes Marin, Institut du Littoral et de l'Environnement, Port des minimes, Av. du Lazaret, 17000 La Rochelle, France \\ ${ }^{\mathrm{g}}$ Department of Pathology, Faculty of Veterinary Medicine, B43 Liège University, 4000 Liège, Belgium
}

\section{A R T I C L E I N F O}

\section{Article history:}

Received 26 March 2014

Received in revised form

2 June 2014

Accepted 5 June 2014

Available online 28 June 2014

Keywords:

Harbour porpoise

Stranding

Metals

Southern North Sea

\begin{abstract}
A B S T R A C T
Throughout the last few years, the southern North Sea has witnessed an increase in the number of stranded marine mammals, particularly the harbour porpoise (Phocoena phocoena). This species is subject to several potential threats such as exposure to contaminants, changes in food supply, marine traffic and fishery by-catch. The aims of this study were to investigate potential associations between contaminants and health status and to analyze spatial and temporal trends of metal concentrations in harbour porpoises. Selected trace elements (As, $\mathrm{Cd}, \mathrm{Cr}, \mathrm{Cu}, \mathrm{Hg}, \mathrm{Mn}, \mathrm{Se}, \mathrm{V}$ and $\mathrm{Zn}$ ) were measured in kidneys and livers of 105 harbour porpoises stranded along the southern North Sea (French and Belgian coasts from 2006 to 2013) and 27 stranded along the Bay of Biscay (French coast from 2009 to 2012). Porpoises that died from infectious disease displayed significant higher hepatic concentrations of $\mathrm{Cd}, \mathrm{Hg}$, Se and $\mathrm{Zn}$ compared to healthy porpoises that died from physical trauma. Adult porpoises displayed significant higher concentrations of $\mathrm{Cd}, \mathrm{Cr}, \mathrm{Hg}$, Se and $\mathrm{V}$ in livers compared to juveniles. No spatial or temporal trends in metal concentrations were detected in our study. The results of the present study suggested that chemical contamination may represent one of many threats encountered by harbour porpoises, but it cannot explain alone the increase in the number of stranded individuals.
\end{abstract}

(c) 2014 Elsevier Inc. All rights reserved.

\section{Introduction}

The harbour porpoise (Phocoena phocoena) is the most common and abundant marine mammal inhabiting the North Sea and adjacent waters. The abundance of porpoises has increased significantly over the last decade along the southern North Sea (Hammond et al., 2013). This species is very sensitive to anthropogenic disturbances, mostly fishery activities such as by-catch and food depletion (Haelters and Camphuysen, 2009; Herr et al., 2009), organic pollutants and metal contaminants (Bennett et al., 2001; Das et al., 2004b) and recently the exponential growth of industrial activity at sea through the construction of offshore wind

\footnotetext{
The present study was funded by The "Grand Port Maritime de Dunkerque" (France).

* Corresponding author at: Université du Littoral, Laboratoire d'Océanologie et de Géosciences, 32 Avenue Foch, BP 8062930 Wimereux, France.

E-mail address: celine.mahfouz@univ-littoral.fr (C. Mahfouz).
}

farms (Haelters, 2009). The North Sea is a productive and biologically rich area, and therefore it provides abundant food for marine mammals. It is regarded as a moderately polluted sea area (OSPAR, 2010). The North Sea is a semi-enclosed sea surrounded by large and highly developed societies. Therefore this area supports intense fishing activities and coastal industrial activities. It is a major navigation route for some of the world's most developed and highly populated economies, thus shipping in the area is the most intense in the world (Ducrotoy and Elliott, 2008).

Due to their role as top predators within the marine food web, marine mammals such as porpoises have been used as indicators for ecosystem changes. Over the last decade, porpoises stranding has increased in French, Belgian and Dutch coastal waters (Haelters and Camphuysen, 2009; Jauniaux et al. 2008). Many studies tried to identify the causes of death and monitored the health status of marine mammals. In the southern North Sea, infectious diseases and bycatch in fishing nets were the two prevailing causes of death (Jepson et al., 1999, Siebert et al., 1999, Jauniaux et al., 2002; Haelters 
and Camphuysen, 2009). However, high levels of metal contaminants have been documented in various studies on marine mammals. For instance, harbour porpoises from England and Wales, northern France, Belgian and German coasts tend to accumulate metal contaminants according to their health status (Bennett et al., 2001; Das et al., 2004a). Correlations between severities of disease and liver $\mathrm{Hg}$ levels were detected in harbour porpoises from the German waters (Siebert et al., 1999). These studies suggested that metal contaminants may have adverse effects on harbour porpoise's health or that metals are redistributed from other tissues to liver during disease or cachexia.

Since chemical contaminants may affect the health of harbour poroises, contamination by metals may be associated with the increased stranding of harbour porpoises in the southern North Sea along northern France and Belgian coasts. Therefore, the aims of the present work were (1) to establish a temporal trend of metal levels in organs of porpoises from the southern North Sea stranded between 2006 and 2013 and to investigate potential associations between metal concentrations and the cause of death (traumatic or infectious) of porpoises; (2) to assess the population status by comparing levels of metal contaminants in organs of porpoises stranded in the southern North Sea to porpoises stranded in the Bay of Biscay (French Atlantic coast) between 2009 and 2012.

\section{Materials and methods}

\subsection{Sampling and data collection}

From 120 harbour porpoises stranded in the southern North Sea along the northern France and Belgian coasts between 2006 and 2013, livers and kidneys were collected for analyses. Similarly in the Bay of Biscay, livers and kidneys were collected from 35 harbour porpoises stranded between 2009 and 2012. According to the protocol from Kuiken and Hartmann (1993) and Jauniaux et al. (2002), postmortem investigations were performed on all freshly dead or slightly decomposed carcasses washed ashore along the southern North Sea. Age groups were determined from the length of individuals. Porpoises with lengths ranging from 91 to $130 \mathrm{~cm}$ were considered as juveniles and animals greater than $130 \mathrm{~cm}$ were considered as adults (Jauniaux et al., 2002). The nutritional status of animals was evaluated according to the blubber thickness measured at the cranial insertion of the dorsal fin. Four categories were identified according to the cause of death of the animal. The first category represented harbour porpoises that died from infectious diseases including parasitic, bacterial, mycotic and viral infections and those that died from lung oedema, pneumonia and emaciations. The second category represented porpoises that died from physical trauma associated to suffocation, traumatic injuries and entanglement in fishing nets. Porpoises who died of other causes (tumour, starvation, etc.) or whose cause of death could not be determined mostly due to the advanced decomposition of carcasses represented the third category. Finally porpoises that died from seal predations represented the fourth category. Livers and kidneys were stored at $-20{ }^{\circ} \mathrm{C}$ in plastic bags until analyses were carried out

\subsection{Metal analysis}

Livers and kidneys were freeze-dried and homogenized with an agate morta and pestle. An aliquot of $150 \mathrm{mg}$ from each material was digested in a concentrated solution of nitric acid (65\%, Suprapur, Merck) at room temperature for $24 \mathrm{~h}$ and then at $100{ }^{\circ} \mathrm{C}$ for $4 \mathrm{~h}$. Metal concentrations (As, $\mathrm{Cd}, \mathrm{Hg}, \mathrm{Pb}$ and $\mathrm{V}$ as non essential elements and $\mathrm{Cu}, \mathrm{Cr}$, Mn, Se and $\mathrm{Zn}$ as essential elements) were determined by an Inductively Coupled Plasma Atomic Emission Spectrometer (ICP-AES, Thermo Scientific iCAP 6500) and Inductively Coupled Plasma Mass Spectrometer (ICPMS, Varian 820-MS) depending on concentration levels of each metal. In order to resolve the matrix effects, a standard addition technique was applied for the determination of As, Cd, Cr, and V on ICP-MS. Metal concentrations are reported in $\mu \mathrm{g} \mathrm{g}^{-1}$ dry weight (dw). For conversion into wet weight (ww) in order to compare with other studies, the following factors according to the weight before and after lyophilisation are applicable: 0.29 for liver and 0.24 for kidney. Limits of quantification were $0.05 \mu \mathrm{g} \mathrm{g}^{-1} \mathrm{dw}$ for $\mathrm{Cd}$ and $\mathrm{Pb}, 0.20 \mu \mathrm{g} \mathrm{g}^{-1} \mathrm{dw}$ for $\mathrm{V}, 0.35 \mu \mathrm{g} \mathrm{g}^{-1} \mathrm{dw}$ for As and $\mathrm{Cr}, 2 \mu \mathrm{g} \mathrm{g}^{-1} \mathrm{dw}$ for $\mathrm{Cu}$, Se and $\mathrm{Mn}$, and $2.5 \mu \mathrm{g} \mathrm{g}{ }^{-1} \mathrm{dw}$ for $\mathrm{Zn}$. Lead concentrations were consistently below the quantification limit and therefore will not be mentioned in the table of results.

Total mercury analyses were conducted on an Advanced Mercury Analyzer Spectrophotometer (AMA-254, Altec). Concentrations were only determined in the livers of harbour porpoises since it is the main storage organ for $\mathrm{Hg}$ (Paludan-Müller et al., 1993). This analyzer allows direct measurements of solid samples, but considering that $\mathrm{Hg}$ is relatively concentrated in the livers of marine mammals, we injected samples in liquid form $(100 \mu \mathrm{L})$ after mineralization. Amounts of $\mathrm{Hg}$ ranging between 0.5 and 2 ng were obtained. This method reduces the effects of memory of the apparatus and allows having a representative weight of the considered sample. The limit of quantification was $0.005 \mu \mathrm{g} \mathrm{g}^{-1} \mathrm{dw}$.

Procedural blanks, replicated analysis and analysis of standard reference material were adapted for quality control procedures. As for standard reference materials, DOLT-4 and DORM-3 (dogfish liver and fish protein, respectively, National Research Council, Canada) were treated and analyzed under the same conditions as samples in order to monitor the above mentioned method sensitivities. Yields from $87 \%$ to $115 \%$ proved that the results were in good agreement with the certified values.

\subsection{Data treatment}

Data analysis was performed using "XLSTAT - Pro" 2013 (Addinsoft). When values were below the limit of quantification, half the limit of quantification was assigned for statistical analyses. Concentrations in livers and kidneys were tested using a MannWhitney U test or a student's $t$-test when the necessary assumptions of normality and homogeneity of variances for parametric statistics were satisfied. These statistical tests were used to compare metal accumulation in juvenile and adult porpoises from the southern North Sea, as well as to compare metal levels between the southern North Sea and the Bay of Biscay. Moreover, metal concentrations were tested using KruskalWallis test followed by the Dunn test for multiple comparisons to check for pairwise differences. These statistical tests were used to delineate the evolution of metal concentrations in livers and kidneys of porpoises from the southern North Sea between 2006 and 2013. Finally, correlations between metals in livers and kidneys were tested using the Spearman coefficient. The level of significance was set at $\alpha=0.05$.

\section{Results}

Mean tissue concentrations of metals determined in livers and kidneys of harbour porpoises from the southern North Sea and the Bay of Biscay are presented in Table 1. The results show that Mn, $\mathrm{Cu}$, Se and $\mathrm{Zn}$ presented higher levels in livers compared to kidneys, whilst $\mathrm{V}$, As and $\mathrm{Cr}$ had almost same levels in both organs. The $\mathrm{Cd}$ element had higher values in kidneys compared to livers. $\mathrm{Zn}$ had the highest mean levels in livers of porpoises stranded in southern North Sea followed by $\mathrm{Cu}, \mathrm{Hg}, \mathrm{Se}, \mathrm{Mn}, \mathrm{As}$, $\mathrm{Cr}, \mathrm{V}$ and $\mathrm{Cd}$. Similar order occurred for metal concentrations in the livers of porpoises from the Bay of Biscay except for Hg which had higher mean levels than $\mathrm{Cu}$. In kidneys of porpoises from the southern North Sea, mean levels in descending order were: $\mathrm{Zn}, \mathrm{Cu}$, $\mathrm{Se}, \mathrm{Mn}, \mathrm{As}, \mathrm{Cd}, \mathrm{Cr}$ and V. Porpoises stranded in the Bay of Biscay, displayed similar order except for $\mathrm{Cd}$ which had higher mean levels than As.

For the geographical comparison, hepatic $\mathrm{Zn}$ concentrations displayed significantly higher levels in porpoises of the southern North Sea compared to porpoises stranded in the Bay of Biscay $(p<0.05)$, whereas $\mathrm{V}$ and As displayed higher levels of hepatic concentrations in porpoises stranded in the Bay of Biscay compared to the southern North Sea area $(p<0.05$ and $p<0.001$, respectively). Other metallic contaminants such as $\mathrm{Cd}, \mathrm{Cr}, \mathrm{Cu}, \mathrm{Hg}$, $\mathrm{Mn}$ and Se showed no significant variations between both studied areas. For renal analysis, results showed that $\mathrm{Cr}, \mathrm{Cu}, \mathrm{Mn}, \mathrm{V}$ and $\mathrm{Zn}$ displayed higher concentrations in the kidneys of porpoises from the southern North Sea compared to animals from the Bay of Biscay $(p<0.05)$, while As, Cd and Se showed no significant interregional variations.

For harbour porpoises stranded in the southern North Sea between 2006 and 2013, correlations in livers $(n=105)$ and kidneys $(n=100)$ between metals are presented in Table 2 . In the livers of porpoises, there was a strong correlation between $\mathrm{Hg}$ and $\mathrm{Se}$ concentrations (Spearman correlation value $R s=0.868, p<0.0001$ ). $\mathrm{Hg}$ was also correlated with $\mathrm{Cd}(p<0.0001), \mathrm{V}(p<0.005)$ and negatively correlated with $\mathrm{Mn}(p<0.05)$. In kidneys, Cd showed significant correlations with $\mathrm{Cu}$, Se and $\mathrm{Zn}$. A significant correlation was also detected between $\mathrm{Cu}$ and $\mathrm{Zn}$ in livers $(p<0.0001)$. A high 
Table 1

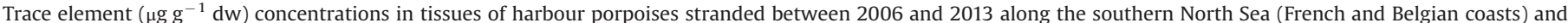
porpoises stranded between 2009 and 2012 in the Bay of Biscay. Mean \pm SD; range of concentrations (minimum - maximum); number of samples.

\begin{tabular}{|c|c|c|c|c|c|c|c|c|c|}
\hline & \multicolumn{9}{|c|}{ Metal concentrations } \\
\hline & Mn & $\mathbf{C u}$ & Se & Zn & $\mathbf{V}$ & As & $\mathrm{Cr}$ & Cd & $\mathbf{H g}$ \\
\hline \multicolumn{10}{|l|}{ Livers } \\
\hline $\begin{array}{l}\text { Southern North Sea } \\
n=105\end{array}$ & $\begin{array}{l}18 \pm 5 \\
(2.4-38)\end{array}$ & $\begin{array}{l}38 \pm 36 \\
(6-320)\end{array}$ & $\begin{array}{l}24 \pm 46 \\
(1.9-311)\end{array}$ & $\begin{array}{l}193 \pm 106 \\
(67-635)\end{array}$ & $\begin{array}{l}0.6 \pm 0.4 \\
(0.2-2.4)\end{array}$ & $\begin{array}{l}2.5 \pm 0.9 \\
(<0.35-6.6)\end{array}$ & $\begin{array}{l}2 \pm 1 \\
(0.6-7)\end{array}$ & $\begin{array}{l}0.4 \pm 0.5 \\
(<0.05-3.3)\end{array}$ & $\begin{array}{l}30 \pm 51 \\
(1.8-292)\end{array}$ \\
\hline $\begin{array}{l}\text { Bay of Biscay } \\
n=25\end{array}$ & $\begin{array}{l}17 \pm 6 \\
(9-28)\end{array}$ & $\begin{array}{l}33 \pm 23 \\
(12-136)\end{array}$ & $\begin{array}{l}24 \pm 31 \\
(2-106)\end{array}$ & $\begin{array}{l}152 \pm 62 \\
(77-303)\end{array}$ & $\begin{array}{l}0.7 \pm 0.4 \\
(0.4-1.76)\end{array}$ & $\begin{array}{l}3.0 \pm 0.9 \\
(1.4-5.2)\end{array}$ & $\begin{array}{l}1.5 \pm 0.2 \\
(1.4-2.4)\end{array}$ & $\begin{array}{l}0.5 \pm 0.5 \\
(<0.05-1.5)\end{array}$ & $\begin{array}{l}45 \pm 67 \\
(2.1-225)\end{array}$ \\
\hline \multicolumn{10}{|l|}{ Kidneys } \\
\hline $\begin{array}{l}\text { Southern North Sea } \\
n=100\end{array}$ & $\begin{array}{l}3 \pm 1.6 \\
(<2-18)\end{array}$ & $\begin{array}{l}16 \pm 4.5 \\
(5-44)\end{array}$ & $\begin{array}{l}11 \pm 3.5 \\
(3.6-22)\end{array}$ & $\begin{array}{l}94 \pm 17 \\
(40-150)\end{array}$ & $\begin{array}{l}0.6 \pm 0.3 \\
(0.2-1.4)\end{array}$ & $\begin{array}{l}2.8 \pm 1 \\
(<0.35-5.5)\end{array}$ & $\begin{array}{l}2 \pm 1 \\
(0.6-4.5)\end{array}$ & $\begin{array}{l}2.3 \pm 3.1 \\
(<0.05-18)\end{array}$ & $\begin{array}{l}- \\
-\end{array}$ \\
\hline Bay of Biscay & $3 \pm 0.7$ & $15 \pm 2.5$ & $12 \pm 6$ & $87 \pm 12$ & $0.4 \pm 0.1$ & $2.4 \pm 1.3$ & $1.1 \pm 0.1$ & $2.8 \pm 2.6$ & - \\
\hline$n=27$ & $2-4$ & $11-22$ & $3-23$ & $68-120$ & $0.2-0.7$ & $0.9-7$ & $0.6-1.3$ & $<0.05-8$ & - \\
\hline
\end{tabular}

correlation was observed between $\mathrm{V}$ and $\mathrm{Cr}$ in livers $(R \mathrm{~s}=0.871)$ and kidneys $(R s=0.955)$ of porpoises $(p<0.0001)$. Similarly to the porpoises stranded in the southern North Sea, almost same correlations between metals were found in livers $(n=25)$ and kidneys $(n=27)$ of porpoises stranded in the Bay of Biscay (Data not shown). $\mathrm{Hg}$ and Se were highly correlated in livers $(R \mathrm{~s}=0.923, p<0.0001) . \mathrm{Hg}$ was also correlated to $\mathrm{Cd}$ and $\mathrm{V}(p<0.0001)$. In kidneys, Cd showed significant correlations between Se, Zn $(p<0.05)$ and V $(p<0.0001)$. For $\mathrm{V}$ and $\mathrm{Cr}$, this correlation is not as pronounced in the case of porpoises from the Bay of Biscay.

\subsection{Metal contaminants and maturity status}

Metal contaminants were determined in livers of 85 juveniles ( 33 females and 52 males) and 18 adults ( 13 females and 5 males). Results (Fig. 1a) showed that adult porpoises displayed significantly higher $\mathrm{Cd}, \mathrm{Cr}, \mathrm{Hg}$, Se and $\mathrm{V}$ hepatic concentrations compared to juveniles $(p<0.05)$. No such differences between juveniles and adults were detected for $\mathrm{As}, \mathrm{Cu}$ and $\mathrm{Zn}$ in livers. Hepatic concentrations of $\mathrm{Cd}, \mathrm{Hg}$ and $\mathrm{Se}$ in adult porpoises were 4, 9 and 6 fold higher than in juvenile porpoises, respectively.

For renal analysis, 79 juveniles (31 females and 48 males) and 19 adults (13 females and 6 males) were analyzed (Fig. 1b). Juveniles exhibited significantly higher As concentrations compared to adults $(p<0.05)$. For $C d$, mean renal concentrations were significantly higher in adult porpoises compared to juveniles $(p<0.05)$. No such differences were detected for $\mathrm{Cr}, \mathrm{Cu}, \mathrm{Mn}$, Se and $\mathrm{V}$ in kidneys between juveniles and adults.

\subsection{Metal contaminants and causes of death}

For porpoises stranded in the southern North Sea between 2006 and 2013, we compared the mean blubber thickness of porpoises that died from physical trauma $(20 \pm 6 \mathrm{~mm})$ and those that died from infectious disease $(14 \pm 6 \mathrm{~mm})$. Statistical analysis showed that porpoises that died from physical trauma displayed significantly mean thicker blubber than porpoises that died from infectious disease (Mann-Whitney, $p<0.0001$ ).

Harbour porpoises that died from infectious diseases $(n=47)$ showed significantly higher mean liver concentrations of $\mathrm{Cd}, \mathrm{Hg}$, $\mathrm{Se}, \mathrm{V}$ and $\mathrm{Zn}$ compared to healthy porpoises $(n=44)$ that died from physical trauma $(p<0.05)$. However porpoises that died from traumas showed significantly higher concentrations of As in the liver compared to those that died from diseases $(p<0.05)$ (Fig. 2a).

In kidneys (Fig. 2b), significant differences for $\mathrm{Cd}, \mathrm{Cr}, \mathrm{Cu}$ and $\mathrm{Zn}$ concentrations were detected in porpoises that died from infectious disease $(n=44)$ compared to those that died from traumas $(n=44)(p<0.05)$. Similarly to the liver, significantly higher concentrations of As were detected in the kidneys of porpoises that died from traumas compared to those that died from diseases $(p<0.05)$.

\section{Discussion}

Exposure to metal contaminants may impair the immune system of marine mammals. High levels of metal contaminants have been documented in various studies on harbour porpoises (Jepson et al., 1999; Siebert et al., 1999; Bennett et al., 2001; Das et al., 2004b). In the present study, metal levels were compared in organs of harbour porpoises stranded in a semi-enclosed sea (North Sea) and in a very large opened bay (Bay of Biscay) (Table 1). Results showed that only Zn element had significant higher concentrations in livers and kidneys of stranded porpoises from the southern North Sea. Porpoises from this area, with high $\mathrm{Zn}$ and poor body condition are already facing stressful conditions such as elevated levels of organochlorines and other toxic compounds (Jepson et al., 1999; Das et al., 2004b). Metal concentrations determined in livers and kidneys of harbour porpoises stranded in the southern North Sea and the Bay of Biscay were within the range of values reported for other porpoises stranded in the southern North Sea (northern France and Belgium) between 1994 and 2001 (Das et al., 2004b) and porpoises stranded on the French coasts between 1997 and 2003 (Lahaye et al., 2007), whereas hepatic and renal concentrations in porpoises from the present study were lower than levels determined in porpoises stranded on the UK coasts between 1989 and 2001 (Jepson, 2003). From a geographical comparison, harbour porpoises from the southern North Sea and the Bay of Biscay may have comparable levels of metallic contaminants in their tissues. However in our study, differences of metal concentrations are much more pronounced taking into account the cause of death rather than the stranding location. Indeed, we have constantly found that porpoises that died from infectious diseases displayed significantly higher $\mathrm{Hg}$, Se, $\mathrm{Zn}, \mathrm{Cd}$ and V levels in their livers compared to those that died from physical trauma. These findings are in agreement with the study of Bennett et al. (2001) who found same trends for $\mathrm{Hg}$, Se and $\mathrm{Zn}$ levels but not for Cd levels, whereas another study showed that $\mathrm{Cu}, \mathrm{Cd}$ and $\mathrm{Hg}$ concentrations in livers and kidneys did not vary significantly with deteriorated health condition (Das et al., 2004b).

\subsection{Non essential elements}

Several studies showed that, among the non essential elements, $\mathrm{Hg}$ is the most concentrated metal in porpoise livers (present study, Bennett et al., 2001; Das et al., 2004b; Ciesielski et al., 2006; Lahaye et al., 2007). Mercury is of particular concern 
Table 2

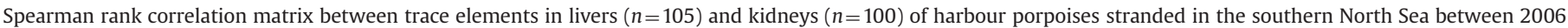
and 2013.

\begin{tabular}{|c|c|c|c|c|c|c|c|c|c|}
\hline & Mn & $\mathrm{Cu}$ & $\mathrm{Se}$ & $\mathrm{Zn}$ & $\mathrm{V}$ & As & $\mathrm{Cr}$ & $\mathrm{Cd}$ & $\mathrm{Hg}$ \\
\hline \multicolumn{10}{|c|}{ Livers } \\
\hline Mn & 1 & & & & & & & & \\
\hline $\mathrm{Cu}$ & $0.360^{* *}$ & 1 & & & & & & & \\
\hline Se & -0.147 & 0.157 & 1 & & & & & & \\
\hline $\mathrm{Zn}$ & $0.281^{* * *}$ & 0.134 & 0.071 & 1 & & & & & \\
\hline V & -0.016 & -0.082 & $0.337^{* *}$ & -0.067 & 1 & & & & \\
\hline As & -0.068 & -0.051 & -0.015 & $-0.297^{* * k}$ & 0.034 & 1 & & & \\
\hline $\mathrm{Cr}$ & -0.010 & -0.033 & $0.262^{*}$ & -0.003 & $0.871^{* * k * k}$ & -0.111 & 1 & & \\
\hline $\mathrm{Cd}$ & -0.152 & 0.027 & $0.411^{* * * * * *}$ & 0.170 & 0.109 & -0.016 & 0.088 & 1 & \\
\hline $\mathrm{Hg}$ & $-0.203^{*}$ & 0.043 & $0.868^{* * * *}$ & 0.129 & $0.286^{* *}$ & -0.033 & 0.173 & $0.458^{* * * *}$ & 1 \\
\hline \multicolumn{10}{|c|}{ Kidneys } \\
\hline $\mathrm{Mn}$ & 1 & & & & & & & & \\
\hline $\mathrm{Cu}$ & $0.434 * * * *$ & 1 & & & & & & & \\
\hline Se & -0.012 & -0.185 & 1 & & & & & & \\
\hline $\mathrm{Zn}$ & $0.321^{* *}$ & $0.476^{* * * *}$ & $-0.247^{*}$ & 1 & & & & & \\
\hline V & -0.004 & $-0.251^{*}$ & -0.008 & -0.026 & 1 & & & & \\
\hline As & 0.056 & -0.143 & $0.249^{*}$ & $-0.409^{* * * *}$ & -0.093 & 1 & & & \\
\hline $\mathrm{Cr}$ & 0.043 & $-0.229^{*}$ & -0.027 & -0.017 & $0.955^{* * * *}$ & -0.084 & 1 & & \\
\hline $\mathrm{Cd}$ & 0.127 & $0.253^{*}$ & $0.294^{* * *}$ & $0.296^{* * *}$ & 0.094 & -0.168 & 0.103 & 1 & \\
\hline
\end{tabular}

$* p<0.05$
$* * * 0.005$

**** $p<0.0001$.
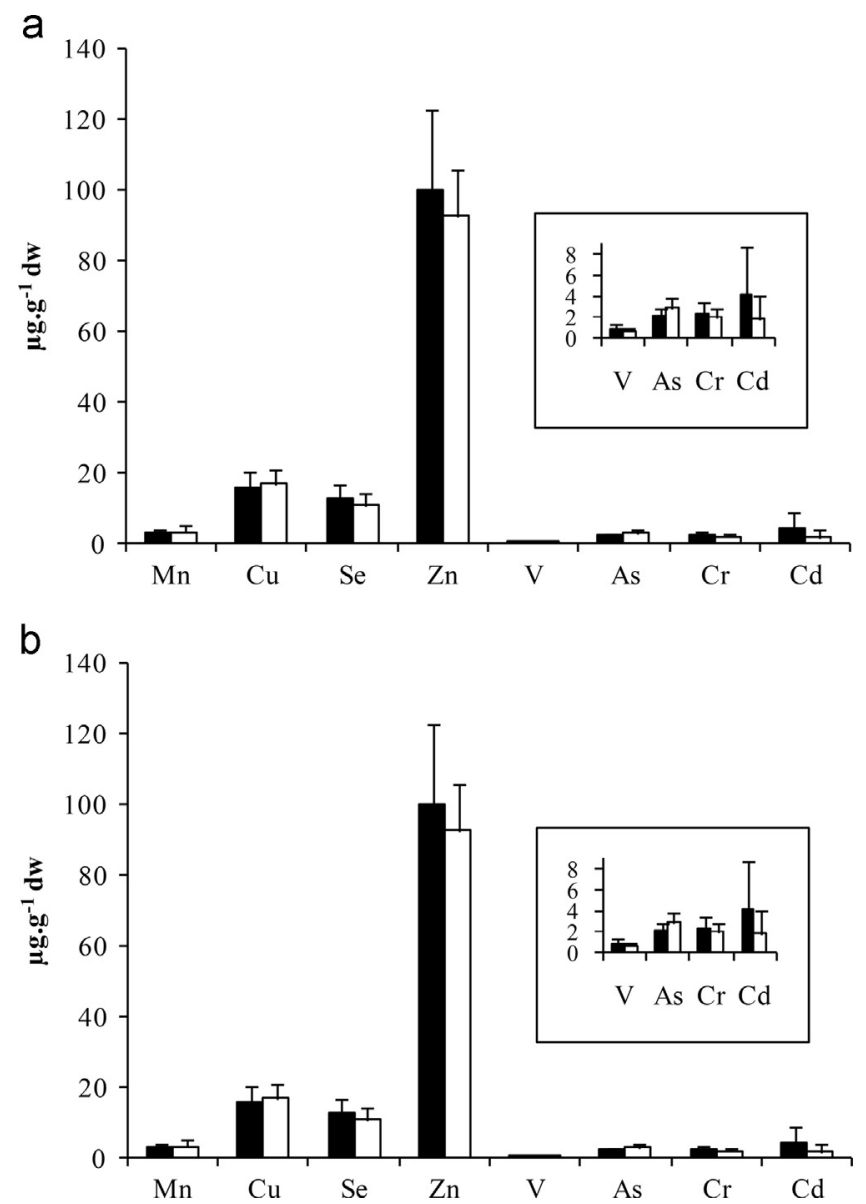

Fig. 1. Mean metal concentrations ( $\mu \mathrm{g} \mathrm{g} \mathrm{g}^{-1} \mathrm{dw}$ ) in livers (a) and kidneys (b) of porpoises stranded along the French and Belgian coasts between 2006 and 2013 according to the maturity status. Black bars represent adult porpoises ( $n=18$, livers and $n=19$, kidneys) and white bars juvenile porpoises ( $n=85$, livers and $n=79$, kidneys).

due to its properties of biomagnifications in the upper levels of the food web, high mobility and persistence in the marine ecosystem (Palmisano et al., 1995; Das et al., 2003). Liver $\mathrm{Hg}$ and $\mathrm{MeHg}$

a

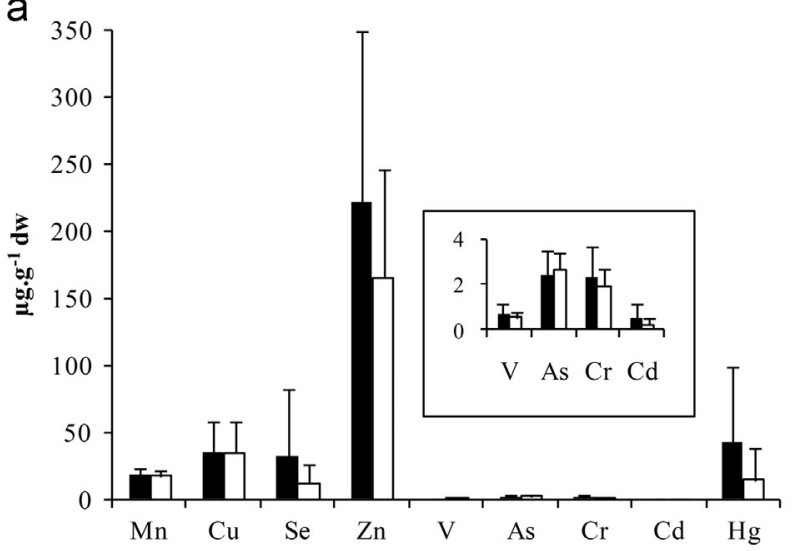

b

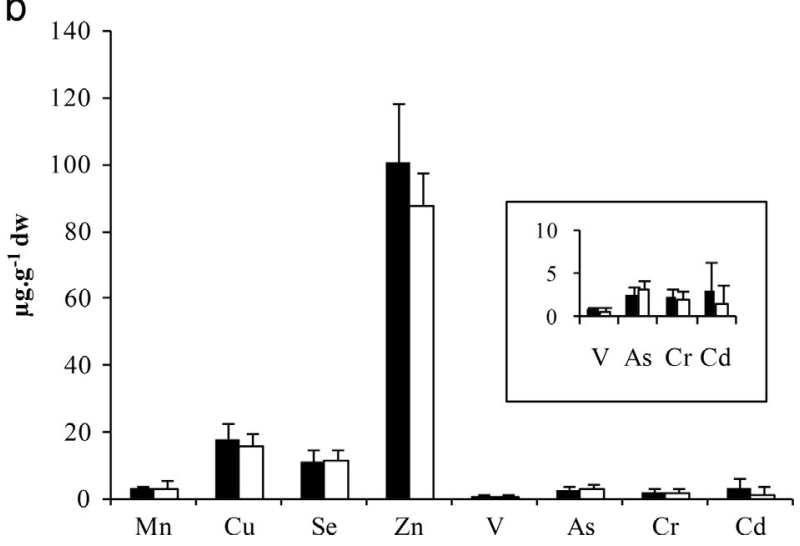

Fig. 2. Mean metal concentrations ( $\mu \mathrm{g} \mathrm{g}^{-1} \mathrm{dw}$ ) in livers (a) and kidneys (b) of porpoises stranded along the French and Belgian coasts between 2006 and 2013 according to the cause of death. Black bars represent porpoises that died from infectious disease ( $n=47$, livers and $n=44$, kidneys) and white bars porpoises that died from physical trauma ( $n=44$, livers and $n=44$, kidneys).

concentrations were associated with the severity of disease in porpoises from the German waters (Siebert et al., 1999). In addition, $\mathrm{Hg}$ can accelerate and exacerbate disease manifestations in inbred strains of mice prone to autoimmune disease (Reviewed 
by Theron et al. (2012)). Total mercury levels in livers of porpoises stranded in the southern North Sea varied widely within individuals; adult porpoises displayed significantly higher hepatic $\mathrm{Hg}$ concentrations compared to juveniles $(p<0.0001)$. For instance, the highest value of mercury ( $292 \mu \mathrm{g} \mathrm{g}^{-1} \mathrm{dw}$ ) was obtained in the liver of a porpoise which age class and sex were undetermined. While the second highest value $\left(276 \mu \mathrm{g} \mathrm{g}^{-1} \mathrm{dw}\right)$ was determined in the liver of an adult female who died from infectious disease. This latter concentration was more than 150 fold higher than the lowest value $\left(1.8 \mu \mathrm{g} \mathrm{g}^{-1} \mathrm{~d}\right.$.w.) determined in the liver of a juvenile male who died after capture. Bioaccumulation of mercury with age has been described in various marine mammal species (Wagemann and Muir, 1984; Wagemann et al., 1996). Consequently, the difference in mercury levels between juveniles and adults is presumably linked to a lower exposure and / or lower prey intake for the juvenile porpoises. It has been proved that in marine mammals mercury is not stored solely as methylmercury (MeHg). Mercury is ingested mainly in its highly toxic form methylmercury. Through a relatively slow biochemical process, $\mathrm{MeHg}$ is biotransformed to the inorganic form and biochemically inert mercury selenide (HgSe). Indeed there was a strong correlation between selenium and mercury concentrations in the livers of porpoises in the present study (Table 2). It is well known that mercury and selenium occurs in a 1:1 $\mathrm{M}$ ratio in marine mammals (Paludan-Müller et al., 1993; Nigro and Leonzio, 1996; Wagemann et al., 1998) only after a certain threshold for the total mercury concentration (Palmisano et al., 1995). Harbour porpoises from the southern North Sea exhibited a Hg:Se molar ratio lower than 1 . Same findings were observed on stranded porpoises along the French coasts between 1997 and 2003 (Lahaye et al., 2007). In fact, porpoises that died from infectious disease displayed significant higher mean $\mathrm{Hg}$ :Se molar ratio compared to those that died from physical trauma (Mann-Whitney, $p<0.05$ ). These results are in agreement with the study of Bennett et al. (2001), who suggested that high $\mathrm{Hg}$ concentrations in livers of porpoises from coastal waters of England and Wales could not be detoxified by available Se since porpoises were already facing infectious diseases. It should be noted that healthy group who died from physical trauma included 43 juveniles and only 2 adults, whereas the infectious disease group included 32 juveniles and 15 adults. In addition, in our study adult porpoises exhibited significantly higher mean molar ratio (0.6) compared to juvenile porpoises (0.4) (Mann-Whitney, $p<0.001$ ). Therefore, the difference in mean $\mathrm{Hg}$ :Se molar ratio in our study may be associated to the maturity status along with the fact that in the infectious disease group with high $\mathrm{Hg}$ concentrations the detoxification process with Se may be limited (Bennett et al., 2001). Hg limit for hepatic damage in liver tissue of marine mammals is estimated to 100$400 \mu \mathrm{g} \mathrm{g}^{-1} \mathrm{ww}$ (350-1400 $\mu \mathrm{g} \mathrm{g}^{-1} \mathrm{dw}$ approximately) (Wagemann and Muir, 1984). Furthermore, a threshold level of $60 \mu \mathrm{g} \mathrm{g}^{-1} \mathrm{ww}$ (200 $\mu \mathrm{g} \mathrm{g}^{-1} \mathrm{dw}$ approximately) was estimated for liver damage in mammals (AMAP 1998). Bennett et al. (2001) did not reject the hypothesis that $\mathrm{Hg}$ exposure may influence the health of harbour porpoises and contribute to their mortality. Only three adult animals from the southern North Sea and two adult animals from the Bay of Biscay exhibited higher hepatic Hg concentrations than the second threshold level estimated by AMAP (1998) $\left(200 \mu \mathrm{g} \mathrm{g}^{-1}\right.$ $\mathrm{dw}$ ) in mammal livers but lower than the first threshold (350 $\mu \mathrm{g} \mathrm{g}^{-1} \mathrm{dw}$ ) estimated by Wagemann and Muir (1984). These animals, exhibiting $\mathrm{Hg}$ levels in their livers higher than the abovementioned estimated threshold, died due to infectious diseases. The variability found in $\mathrm{Hg}$ concentrations may be related to differences in methylmercury elimination capacity and/or age related storage of detoxified forms among individuals (Nigro and Leonzio, 1996). In this study, most of the Hg levels were below the estimated threshold and the mean $\mathrm{Hg}$ :Se molar ratio was below the unit. These findings suggest that harbour porpoises from the southern North Sea may not be exposed to high levels of $\mathrm{Hg}$ and therefore $\mathrm{Hg}$ levels in livers were not sufficient to induce tiemannite granules as result of coprecipitation of $\mathrm{Hg}$ with Se. We urge caution in such interpretation since stranded animals in this study were predominantby younger age of porpoises.

Unlike mercury which is known for its accumulation in livers, renal tissues were typically higher in Cd levels than hepatic tissues (Wagemann and Muir, 1984; Paludan-Müller et al., 1993). Indeed, our study also revealed that $\mathrm{Cd}$ concentrations in kidneys were significantly higher than liver concentrations (Mann-Whitney, $p<0.0001$ ). In both organs, $\mathrm{Cd}$ concentrations were significantly higher in adult porpoises compared to juveniles (Fig. 1). Uptake from water and food (trophic transfer) are several sources contributing to metal accumulation in marine animals (Wang and Rainbow, 2010). High Cd concentrations have been reported previously in livers and kidneys of marine mammals suggesting that oceanic cephalopods constituted a significant part of their diet (Bustamante et al., 1998; Das et al., 2000) or that marine mammals were ingesting prey from polluted areas (Wagemann and Muir 1984). Indeed, in marine trophic food chains the oceanic cephalopods are considered as an important source of $\mathrm{Cd}$ for top predators (Bustamante et al., 1998). Several authors reported different feeding habits related to sex and/or age in harbour porpoises. For instance, adult female porpoises fed at a higher trophic level than adult males, while no differences as a function of sex were detected for juvenile porpoises (Das et al., 2004a). Evidence of sex or age related variation in diet may be consistent with opportunistic predation. Differences in diet between adult and juvenile porpoises have been found in several studies. Some prey species are more important in the diet of young porpoises, such as gobies (Gobiidae) and shrimps, compared to adult ones (Santos et al., 2004). Santos and Pierce (2003) suggested that juveniles cannot dive as deep as adults and could be limited by their small size from catching and eating big prey. Furthermore, the bioaccumulation of Cd element with age in marine mammal species has been well described (Mackey et al., 1996; Anan et al., 2002; Ikemoto et al., 2004; Harper et al., 2007). Our data suggest that the different Cd levels between juveniles and adults may be related to the maturity status, the bioaccumulation with age along with the differences in the feeding habits between juveniles and adults. We found a significant correlation between $\mathrm{Cd}$ and Se in livers and kidneys of stranded porpoises (Table 2). This correlation is probably not a result of a biochemical interaction. It is more likely due to the fact that both elements are age-dependent; the interactions of $\mathrm{Hg}$ and Se probably lead to age-dependent accumulation of Se in livers (Paludan-Müller et al., 1993; Anan et al., 2002).

For the other two non essential elements considered in this study, differences in concentrations according to the maturity status were less pronounced than $\mathrm{Hg}$ and $\mathrm{Cd}$ elements. Arsenic, showed no differences in the liver of porpoises in both juveniles and adults (Fig. 1a). In kidneys, the As element showed significantly higher concentrations in juveniles (Fig. 1b). Moreover, porpoises that died from physical trauma showed significantly higher concentrations of As than porpoises that died from infectious disease in both livers and kidneys (Fig. 2). It should be mentioned that juvenile porpoises represent more than $89 \%$ of porpoises that died from physical trauma. Thus, the significantly higher As concentrations found in porpoises that died of physical trauma might be influenced by the higher proportion of younger animals in this group rather than the cause of death of porpoises. Frouin et al. (2010) showed that high As concentrations were able to induce genotoxic effects in a harbour seal cell line, and therefore produce alterations in the immune function, which may decrease resistance to infectious diseases encountered in marine mammals. In our study, As concentrations were within the range of values 
reported for various stranded marine mammals. For instance, California sea lions from southern California (Harper et al., 2007) and bottlenose dolphins from south Carolina and Florida waters (Stavros et al., 2011). The bottlenose dolphins from this latter study also exhibited same range of $\mathrm{V}$ levels in their livers compared to porpoises stranded in our study. Moreover, the present hepatic V levels were in the same order of magnitude compared to those reported in other marine mammals such as, Beluga whales (Mackey et al., 1996), various pinnipeds (Saeki et al., 1999) and Caspian seals (Anan et al., 2002). An increase in the concentrations of $\mathrm{V}$ with age has been reported in several species of marine mammals and in addition V levels were correlated with Hg levels in the liver (Mackey et al., 1996; Saeki et al., 1999; Anan et al., 2002; Ikemoto et al., 2004; Stavros et al., 2011). Similarly, adult porpoises showed significant higher levels of $\mathrm{V}$ in livers compared to juveniles and a significant correlation was found between hepatic $\mathrm{V}$ and $\mathrm{Hg}$ accumulation (Table 2). It has been suggested that the correlation of $\mathrm{Hg}$ and $\mathrm{V}$ in livers with aging was caused by the increase in the nuclei and mitochondria fraction since these hepatic elements existed mainly in these cells. Hence $\mathrm{V}$ may be accumulated in the tissues as a contaminant similar to $\mathrm{Hg}$ (Saeki et al., 1999).

\subsection{Essential elements}

Apart from Se, $\mathrm{Zn}$ and $\mathrm{Cu}$ concentrations were also significantly correlated with $\mathrm{Cd}$ concentrations in kidneys of porpoises stranded in the southern North Sea (Table 2). Another study suggested that $\mathrm{Zn}$ and $\mathrm{Cd}$ correlation is due to the fact that $\mathrm{Cd}$ bonds to the zinc-metallothionein, which in turn induces the synthesis of new zinc-metallothionein (Paludan-Müller et al., 1993). The primary function of metallothioneins is the homoeostatic regulation of essential metals as $\mathrm{Cu}$ and $\mathrm{Zn}$. Moreover metallothioneins are able to bind non-essential metals such as $\mathrm{Cd}$ and $\mathrm{Hg}$ (Reviewed by Das et al. (2003)). Therefore, the functions of metallothioneins are considered to be metal storage / detoxification of non-essential metals ( $\mathrm{Cd}$ and $\mathrm{Hg}$ ) or homoeostatic regulation of essential metals ( $\mathrm{Zn}$ and $\mathrm{Cu}$ ) (Reviewed by Wang and Rainbow (2010)). This correlation between toxic Cd and essential $\mathrm{Cu}$ and $\mathrm{Zn}$ would suggest induction of metallothioneins and possible competition or increase in metal binding sites (Wagemann et al., 1988). Whereas other studies who found no correlation between cited metals suggested that the low $\mathrm{Cd}$ concentrations to which porpoises may be exposed in European waters are probably not sufficient to induce $\mathrm{Cu}$ and / or $\mathrm{Zn}$ ion displacement from metallothioneins and consequently leading to co-accumulation with Cd (Lahaye et al., 2007). Das et al. (2004b) suggested that porpoises from the southern North Sea, which are already facing stressful conditions such as elevated levels of organochlorines and other toxic compound, could be exposed to an additional source of stress due to a combination of high $\mathrm{Zn}$ and $\mathrm{Hg}$ levels and poor body condition. $\mathrm{Zn}$ concentrations in our study were not significantly different between adults and juveniles. These results were in agreement with the study of Bennett et al. (2001) who showed no accumulation of $\mathrm{Zn}$ with age. $\mathrm{Zn}$ concentrations have been rather related to disease status. For instance, high $\mathrm{Zn}$ concentrations in porpoises that died of infectious disease may represent a response to infection and other stressors (like cold) causing $\mathrm{Zn}$ redistribution (Bennett et al., 2001). Furthermore, porpoises displaying lesions of the respiratory tract had higher hepatic $\mathrm{Zn}$ burden than porpoises without lung lesions (Das et al., 2004b). The exposition of seals to high Zn concentrations in Caspian Sea resulted in the disturbance of homoeostatic control and nutritional status of essential elements (Anan et al., 2002). Similarly, in our study porpoises from the southern North Sea that died from infectious disease showed significantly higher levels of
Zn compared to those that died from physical trauma (Fig. 2). Hence the blubber thickness of infected porpoises was $12.9 \pm 6.4 \mathrm{~mm}$, which was significantly lower than healthy porpoises that died from physical trauma $(19.8 \pm 5.9 \mathrm{~mm})$ (KruskalWallis; $p<0.0001$ ). Accordingly, high Zn concentrations may be linked to a deteriorated body condition and nutritional status.

High correlation between $\mathrm{Cr}$ and $\mathrm{V}$ was observed in livers and kidneys of porpoises (Table 2). Similarly to $\mathrm{V}, \mathrm{Cr}$ was also correlated with age in livers. Adult porpoises displayed significantly higher levels of hepatic $\mathrm{Cr}$ compared to juveniles (Fig. 1a). Therefore, this observed correlation between $\mathrm{V}$ and $\mathrm{Cr}$ may be related to an age-dependant bioaccumulation. $\mathrm{Mn}$ and $\mathrm{Cr}$ are essential trace elements (Theron et al., 2012) hence slightly variable from animal to animal. Mn is required as a cofactor in at least two classes of enzymes, phosphotransferases and arginases (Mackey et al., 1995). When compared with harbour porpoises from other regions, $\mathrm{Mn}$ and $\mathrm{Cr}$ levels appear to be in the same order of magnitude than those reported in previous works (Bennett et al., 2001; Szefer et al., 2002; Ciesielski et al., 2006; Aubail et al., 2013).

\subsection{Temporal trends}

From 2006 to 2013, we compared the mean metal concentrations in livers and kidneys of porpoises stranded in the southern North Sea. The number of stranded porpoises ranged between 9 stranded animals for the year 2006 and 16 stranded animals for 2007. Statistical analysis showed that in both livers and kidneys, no significant differences were found in metal concentrations along the years 2006 to 2013. In order to broaden the period for comparison, we may compare our results with previous work (Das et al., 2004b). Elements such as $\mathrm{Zn}, \mathrm{Cd}, \mathrm{Cu}, \mathrm{Fe}$, Se and $\mathrm{Hg}$ were determined in liver, kidney and muscle of harbour porpoises from northern France and Belgium (almost same area as the present study) stranded between 1994 and 2001. Metal levels were almost similar in both studies. Hg superior limits were higher in porpoises stranded between 1994 and 2001, whereas Se limits were lower (344 vs. $292 \mu \mathrm{g} \mathrm{g}^{-1} \mathrm{dw}$ and $99 \mathrm{vs}$. $311 \mu \mathrm{g} \mathrm{g}^{-1} \mathrm{dw}$ for $\mathrm{Hg}$ and Se in periods 1994-2001 and 2006-2013, respectively). Porpoises from the southern North Sea (1994-2001) displayed high $\mathrm{Zn}$ and $\mathrm{Hg}$ concentrations compared to porpoises from Norwegian waters and Baltic Sea. This variation was linked to both differences in pollutant exposure and nutritional status between individuals (Das et al., 2004b). The results of our study are in agreement with these findings. As already mentioned, $\mathrm{Zn}$ and $\mathrm{Hg}$ concentrations were significantly higher in porpoises that died from infectious diseases. However Das et al. (2004b) showed that the increase in $\mathrm{Hg}$ and Se with deteriorating body condition in porpoises was not significant, whereas in our study $\mathrm{Hg}$ and Se levels were higher in infected porpoises that died between 2006 and 2013. Considering the metallic concentration levels in organs, we may assume that the population status has been stable from 1994 to 2013. Human activities and changes in emission of pollutants have a noticeable effect on the trace metal and organic pollutant levels in rivers and coastal zones. The recent study of Gao et al. (2013) showed that there is a general decrease of chemical pollution in the southern North Sea (Belgian coastal zone and Scheldt River and Estuary). These authors related the chemical pollution decrease to a decrease in atmospheric and aquatic emissions related to industrial, transportation and domestic activities. Therefore, the stable metal concentrations in porpoises organs stranded between 1994 and 2013 may be related to the decrease of chemical pollution in the environment.

\section{Conclusion}

In the present study a passive monitoring of stranded animals was presented, which can provide insight into environmental 
impacts on marine mammals. Levels of $\mathrm{Hg}, \mathrm{Se}, \mathrm{Zn}, \mathrm{Cd}$ and $\mathrm{V}$ appeared to be higher in porpoises that died from infectious diseases compared to healthy porpoises that died from physical trauma, although synergetic effects of metallic contaminants on health status was not elucidated. Our findings indicate that we cannot reject the hypothesis that metallic contaminants may influence the health of harbour porpoises and contribute to the increased stranding encountered over the last decade for the population in the southern North Sea. This leads us to the fact that the contamination status in the southern North Sea may represent one of the many threats encountered by the harbour porpoises population in this area. Furthermore, the SCANS surveys (1994) showed that porpoises were encountered in the North and Celtic seas except for the channel and southern part of the North Sea (Hammond et al., 2002). These highest densities that were encountered in northern areas in 1994 showed a south shifting in 2005 (Hammond et al., 2013). The authors suggested that the cause of this shifting may be likely due to a change in the distribution and/or availability of harbour porpoises preys. Therefore, several threats such as habitat degradation and climate change may affect distribution and availability of preys (Harwood, 2001). Further work is required to evaluate whether southward shifting population may be related to prey availability which may contribute to the strikingly increase stranding.

\section{Acknowledgement}

The samples used in this study were collected by the French Stranding Network. The "Grand Port Maritime de Dunkerque" (France) is acknowledged for the financial support of this study. Mahfouz Celine is financially supported by a PhD fellowship from the National Council for Scientific Research (Lebanon) and Université du Littoral Côte d'Opale (France). We would like to thank two anonymous reviewers for their helpful comments on an earlier version of this manuscript.

\section{References}

AMAP, 1998. Artic Monitoring and Assessment Programme. AMAP Secretariat, Oslo (AMAP Assessment Report: Arctic Pollution Issues).

Anan, Y., et al., 2002. Elevated concentrations of trace elements in Caspian seals (Phoca caspica) found stranded during the mass mortality events in 2000. Arch. Environ. Contam. Toxicol. 42, 354-362.

Aubail, A., et al., 2013. Use of skin and blubber tissues of small cetaceans to assess the trace element content of internal organs. Mar. Pollut. Bull. 76, 158-169.

Bennett, P.M., et al., 2001. Exposure to heavy metals and infectious disease mortality in harbour porpoises from England and Wales. Environ. Pollut. 112, 33-40.

Bustamante, P., et al., 1998. Cephalopods as a vector for the transfer of cadmium to top marine predators in the north-east Atlantic Ocean. Sci. Total Environ. 220, $71-80$.

Ciesielski, T., et al., 2006. Interspecific distribution and co-associations of chemical elements in the liver tissue of marine mammals from the Polish Economical Exclusive Zone, Baltic Sea. Environ. Int. 32, 524-532.

Das, K., et al., 2003. Heavy metals in marine mammals. In: Vos, JG, Bossart, G, Fournier, M, O'Shea, T. (Eds.), Toxicology of Marine Mammals, Edited by Taylor and Francis Publishers, Washington D.C, pp. 135-167.

Das, K., et al., 2004a. Trace metal and stable isotope measurements ( $813 \mathrm{C}$ and $815 \mathrm{~N}$ ) in the harbour porpoise Phocoena phocoena relicta from the Black Sea. Environ. Pollut. 131, 197-204.

Das, K., et al., 2000. Tuna and dolphin associations in the north-east atlantic: evidence of different ecological niches from stable isotope and heavy metal measurements. Mar. Pollut. Bull. 40, 102-109.

Das, K., et al., 2004b. Ecological and pathological factors related to trace metal concentrations in harbour porpoises Phocoena phocoena from the North sea and adjacent areas. Mar. Ecol. Prog. Ser. 281, 283-295.

Ducrotoy, J.-P., Elliott, M., 2008. The science and management of the North sea and the Baltic sea: natural history, present threats and future challenges. Mar. Pollut. Bull. 57, 8-21.

Frouin, H., et al., 2010. Toxic effects of various pollutants in 11B7501 lymphoma B cell line from harbour seal (Phoca vitulina). Toxicology 270, 66-76.
Gao, Y., et al., 2013. Evolution of trace metal and organic pollutant concentrations in the Scheldt river basin and the Belgian coastal zone over the last three decades. J. Mar. Syst. 128, 52-61.

Haelters, J., Camphuysen, K., 2009. The harbour porpoise in the Southern North Sea: Abundance, threats and research- \& management proposals. Royal Belgian Institute of Natural Sciences (RBINS/MUMM) and the Royal Netherlands Institute for Sea Research (NIOZ). International Fund for Animal Welfare (IFAW) (Report).

Haelters, J., 2009. Monitoring of marine mammals in the framework of the construction and exploitation of offshore wind farms in Belgian marine waters. In: Degraer, S, Brabant, R (Eds.), Offshore Wind Farms in the Belgian Part of the North Sea: State of the Art After Two Years of Environmental Monitoring. Royal Belgian Institute of Natural Sciences, Department MUMM, Brussels, Belgium, pp. 237-266.

Hammond, P.S., et al., 2002. Abundance of harbour porpoise and other cetaceans in the North sea and adjacent waters. J. Appl. Ecol. 39, 361-376.

Hammond, P.S., et al., 2013. Cetacean abundance and distribution in European Atlantic shelf waters to inform conservation and management. Biol. Conserv. $164,107-122$.

Harper, E.R., et al., 2007. Tissue heavy metal concentrations of stranded California sea lions (Zalophus californianus) in Southern California. Environ. Pollut. 147, 677-682.

Harwood, J., 2001. Marine mammals and their environment in the twenty-first century. J. Mammal. 82, 630-640.

Herr, H., et al., 2009. Spatio-temporal associations between harbour porpoise Phocoena phocoena and specific fisheries in the German Bight. Biol. Conserv. 142, 2962-2972.

Ikemoto, T., et al., 2004. Comparison of trace element accumulation in Baikal seals (Pusa sibirica), Caspian seals (Pusa caspica) and northern fur seals (Callorhinus ursinus). Environ. Pollut. 127, 83-97.

Jauniaux, T., et al., 2002. Post-mortem findings and causes of death of harbour porpoises (Phocoena phocoena) stranded from 1990 to 2000 along the coastlines of Belgium and northern France. J. Comp. Pathol. 126, 243-253.

Jauniaux, T., et al., 2008. Causes of death of harbor porpoises (Phocoena phocoena) stranded on the continental coastline of the southern North Sea (Belgium, France, and Dutch coasts) between 1990 and 2007. In: Proceedings of the ICES Annual Science Conference, Halifax, Canada, ICES CM 2008/D: 09.

Jepson, P.D., et al., 1999. Investigating potential associations between chronic exposure to polychlorinated biphenyls and infectious disease mortality in harbour porpoises from England and Wales. Sci. Total Environ. 243-244, 339-348.

Jepson, P.D., 2003. Pathology and Toxicology of Stranded Harbour Porpoises (Phocoena phocoena) in UK Waters (Ph.D. thesis). Royal Veterinary College, University of London. 221p.

Kuiken, T., Hartmann, M.G., 1993. In: Proceedings of the first ECS workshop on cetacean pathology dissection techniques and tissue sampling. European Cetacean Society, Leiden.

Lahaye, V., et al., 2007. Biological and ecological factors related to trace element levels in harbour porpoises (Phocoena phocoena) from European waters. Mar. Environ. Res. 64, 247-266.

Mackey, E.A., et al., 1996. Bioaccumulation of vanadium and other trace metals in livers of Alaskan cetaceans and pinnipeds. Arch. Environ. Contam. Toxicol. 30, 503-512.

Mackey, E.A., et al., 1995. Trace element concentrations in cetacean liver tissues archived in the National Marine Mammal Tissue Bank. Sci. Total Environ. 175, 25-41.

Nigro, M., Leonzio, C., 1996. Intracellular storage of mercury and selenium in different marine vertebrates. Mar. Ecol. Prog. Ser. 135, 137-143.

OSPAR, 2010. Quality Status Report 2010. OSPAR Commission, London, 176p.

Palmisano, F., et al., 1995. Speciation of mercury in dolphin liver: a two-stage mechanism for the demethylation accumulation process and role of selenium. Mar. Environ. Res. 40, 109-121.

Paludan-Müller, P., et al., 1993. Mercury, cadmium, zinc, copper and selenium in harbour porpoise (Phocoena phocoena) from West Greenland. Polar Biol. 13, $311-320$.

Saeki, K., et al., 1999. Vanadium accumulation in pinnipeds. Arch. Environ. Contam. Toxicol. 36, 81-86.

Santos, M.B.A., Pierce, G.J., 2003. The diet of harbour porpoise (Phocoena phocoena) in the northeast atlantic. Oceanography and marine biology. Annu. Rev. 41, 355-390.

Santos, M.B., et al., 2004. Variabilty in the diet of harbour porpoises (Phocoena phocoena) in Scottish waters 1992-2003. Mar. Mamm. Sci. 20, 1-27.

Siebert, U., et al., 1999. potential relation between mercury concentrations and necropsy findings in cetaceans from sgerman waters of the north and baltic seas. Mar. Pollut. Bull. 38, 285-295.

Stavros, H.-C.W., et al., 2011. Correlation and toxicological inference of trace elements in tissues from stranded and free-ranging bottlenose dolphins (Tursiops truncatus). Chemosphere 82, 1649-1661.

Szefer, P., et al., 2002. Intercomparison studies on distribution and coassociations of heavy metals in liver, kidney, and muscle of harbor porpoise, Phocoena phocoena, from southern Baltic sea and coastal waters of Denmark and Greenland. Arch. of Environ. Contam. Toxicol. 42, 508-522.

Theron, A.J., et al., 2012. Harmful interactions of non-essential heavy metals with cells of the innate immune system. J. Clin. Toxicol. S3, 005, http://dx.doi.org/ 10.4172/2161-0495.S3-005. 
Wagemann, R., Muir, D.C.G., 1984. Concentrations of heavy metals and organochlorines in marine mammals of northern waters: overview and evaluation Canadian Technical Report of Fisheries and Aquatic Sciences, 1279, 97p.

Wagemann, R., et al., 1988. Trace metals and methyl mercury: associations and transfer in harp seal (Phoca groenlandica) mothers and their pups. Mar. Mamm. Sci. 4, 339-355.

Wagemann, R., et al., 1996. Overview and regional and temporal differences of heavy metals in Arctic whales and ringed seals in the Canadian Arctic. Sci. Total Environ. 186, 41-66.
Wagemann, R., et al., 1998. Methylmercury and total mercury in tissues of arctic marine mammals. Sci. Total Environ. 218, 19-31.

Wang, W.X., Rainbow, P.S., 2010. Significance of metallothioneins in metal accumulation kinetics in marine animals. Comp. Biochem Physiol.. Part C 152 (1-8). 